Gurung, Harka1987 Himali Chhetrama Baudha Dharma ("Buddhism in Himalayan Region"). A paper presented in the first national Buddhist Conference in Kathmandu.

2001 Janaganana-2001 E. Anusar Jatiya Tathyanka Prambhik Lekhajokha ("Ethinc Data in accordance to the Cencus of 200I A.D.: Preliminary Assessment"). Kathmandu: Dharmodaya Sabha.

Guvaju, Tilak Man1990 Ke Buddhadharma Hindudharmako Sakha Ho Ra? ("Is Buddhism a Branch of Hinduism?"). Pokhara, Nepal: Sriprasad Tamu. (Text in Nepali).

Mukunda, Acharya et al.2000 Radio Style Book. Kathmandu: Radio Nepal.

SPOTLIGHT 1999 SPOTLIGHT. Vol. 19, Number 19, November 26December 2, 1999.

Wadia, A.S. 1992 The Message of Buddha. Delhi: Book Faith India. (First published in 1938).

Weber, Max 1967 The Religion of India. The Sociology of Hinduism and Buddhism. Translated and Edited by Hans H. Gerth and Don Martindale. New York: The Free Press, 1967

\title{
CULTURE AND POLITICS OF CASTE IN THE HIMALAYAN KINGDOM
}

Tulshi Ram Pandey

This paper defines the concept of caste as it can be derived from the literature and attempts to highlight the modality of its manifestations in the context of Nepal. It argues that caste as an ideology or a system of values should not be taken as a face value while it is judged in terms of its application in field reality. Evidences from its practice in Nepal do suggest that it is highly molded by the cultural context of society and political interest of the rulers. Many of its ideological elements apply only partially in field situations.

\section{Defining the Concept of Caste}

Indeed, the division of the population into a number of caste groups is one of the fundamental features of social structure in Hindu society. In these societies, one can encounter with different groups of people identified by a variety of caste names. Even in Nepal, the prevalence of such a division of the population is evident from the fact that the national census of 2001 presents demographic information for more than one hundred caste/ethnic groups. Caste division as a feature of Nepalese society can be discerned not only at its macro national level. Even in micro settings like individual villages, people are divided into a number of caste groups. Let us begin our discussion by settling the meaning of the concept of 
ably in the text), Vaishya and Sudra are located in the order of hierarchy between these extreme categories.

Brahmans, Kshatriyas, Vaisyas and Sudras are the four fold categories of the Varna system. This system keeps the "Untouchables" out from its domain. However all the above five categories are ranked linearly in terms of relative superiority of their status in the hierarchy of caste system. Nevertheless, the interval of status differences or the level of purity or impurity between these broader categories is not linear. Dumont has the following observation about the rules of this type of hierarchical ordering (Dumont 1972: 106). The hierarchy of the Varnas can also be seen:

As a series of successive dichotomies or inclusions. The set of the four varnas divides into two: the last category, that of the Sudras, is opposed to the block of the first three, whose members are 'twice-born' in the sense that they participate in initiation, second birth, and in the religious life in general. These twice-born in turn are divided into two: the Vaisyas are opposed to the block formed by the Kshatriyas and the Brahmans, which in turn divides into two.

By this rule, it can be said that the four Varnas as touchable to each other also form a single block of the pure castes given the uniformity of rules that govern their relation with the "untouchables."

The above five are the broader level categories, which represent the prototype of caste classification at ideological level. In field reality, we confront with a multitude of human groups identified by a variety of caste names. Such a context raises a curiosity to get an understanding of the type of relationship that exists between them and the broader categories.
Indeed, all caste categories are linked to each other by a structural principle. It has already been mentioned that the notion of relative purity or pollution involved in tasks specialized by different category of the population is the foundation at which the four Varnas and the "Untouchables" are ranked in caste hierarchy at the broader level. The members of these groups are also required to follow a number of other rules and regulations related to food habits, marital practices, rites and rituals of lifecycle ceremonies and other types of social relations to preserve the purity of their caste. However, it is not true that all members of each group always fulfill these regulations perfectly. Whenever, some of the members of a caste violate the rules of their caste group, it is possible that the violation will divide the group in to a number of sub-caste categories. The status or rank of these sub-groups is determined by the extent at which their members have violated those rules.

A caste may be divided into a number of sub-caste categories through three important ways.

One such a way appears in the form of portioning out of caste status to its members in different ways (Béteille 1964). It happens in those conditions when some of the members of a caste fulfill some rules of the group only partially, or violate some provisions of those rules tolerably. These types of violations are tolerable to other members of the group that they do not exclude the violators from their caste. However, they divide themselves into differentially named caste segments with relative differences of their status within the umbrella of the original caste. This process has provided the caste system a segmentary character.

The sub-castes may emerge also by way of fusion of diverse groups into new categories (Karve 1961). Marital relation between partners of different castes is the important way that sets opportunity for such a fusion of the groups. Hypergamy is among the accepted 
forms of marriage in Hindu society. People establish even the hypogamous type of marital relations even though these types of practices are not encouraged by caste rules. The progenies born of parents from both of these types of unions comprise a separate category of sub-caste within the caste group at which they are incorporated.

A third method of the division of a caste into sub-caste categories is manifested in different forms. It happens particularly when the territorial subdivisions of a caste meet together within a single locality. In such a condition, none of these divisions is prepared to fuse with or accept the supremacy of the others. Rather, each of them preserves a separate identity by claiming its supremacy over the others.

The processes discussed above only express the theoretical possibilities. In practice, these processes may not operate uniformly in all field realities. Caste as a system of social organization may have, therefore, its local specificity. As a result, the cultural contest of Nepal has contributed to develop some uniqueness even in its caste structure.

\section{Cultural Context and the Caste System}

Above discussion on the concept of caste has noted already that the notion of purity and pollution, food taboos and commensality regulations, restrictions on occupational choice and the requirement of endogamous form of marital practices are the ideological features of caste system in Hindu society. These features play fundamental role to govern the relationship among people within and between the caste groups. However, it has also been explored that the cultural context of a zone or a region affects the extent of rigidity in the application of these rules (Hutton 1963).
The ethnic and religious makeup of a population and the span of time lapsed in the process of interconnection between them set the cultural context of a society. These features have a unique combination in the context Nepal, since this country also forms a distinct type of cultural zone in the South Asian region. Such uniqueness found in the culture of Nepal is a result of its location between the countries with two different cultural traditions. To its north, people in the Tibetan region of China follow a cultural pattern based on Buddhism in its Lamaist form. To its south in the plain land of India, caste Hindus are dominant. The ancestry of people that comprises the population of present day Nepal has been derived from both of these directions. This event has contributed to develop Nepal as a contact zone of cultures originated at both of these neighboring regions.

One example of Nepal being a contact zone of two different cultural traditions can be found in the linguistic diversity of its population. The population census taken in the year 2001 has shown that Nepal has 92 types of known languages spoken as mother tongue by her people. More than 48 percent of this population speaks Nepali as the mother tongue. This language is also used as the official language of the nation and the lingua franca of communication. A substantial proportion of the population also speaks Maithili, Bhojpuri, Tharu and Awadhi languages of Indo-Aryan family. There are also some larger groups of people who speak Tamang, Newar, Magar, Bantawa, Limbu, Sherpa, and other languages that belong to Tibeto-Burman language family (see CBS 2002: Table 19).

People of Nepal also differ in terms of their religious beliefs and practices. Hinduism is the dominant form of religion observed by more than 78 percent of the population. The second most popular religion, defined in terms of numerical strength of the followers, is 
Buddhism. It is followed by 10.5 percent of the total population. The followers of other religious traditions such as Islam, Christianity, Jainism, Sikh, Kirant, etc. are proportionately small (Dahal 2003).

As a society inhabited by overwhelming majority of Hindu population, one of the important features of social organization of Nepal is the division of that population into different caste and subcaste categories. The 2001 population census has presented information on 103 "caste and ethnic" categories (Dahal 2003). Such a categorization has been made to produce data for administrative intention, in which both the caste and ethnic groups are classified together into a single system. This classification does not provide an exhaustive list of all caste, sub-caste and ethnic groups of people living in different parts of the country. Some caste or the ethnic groups are reported only in their generic form, whereas some others are listed even in terms of their sub-divisions. This classification does not provide, therefore, an exhaustive list of all caste, sub-caste and ethnic categories. Indeed, preparation of a comprehensive list of these categories is a difficult exercise. One may define them in different ways according to ones own requirements.

There are some reasons for the availability of such a liberty to delegating a specific type of caste or ethnic identity to different category of the population. One such reason may be found in the provisions of the Civil Code enacted in 1854, as will be discussed below, which have attempted to incorporate all categories of people within the framework of the caste system. Even the constitutions of Nepal formulated after the 1950 have made no mention of the caste or the ethnic identity of any specific group of the population. The ethnic groups in Nepal were considered even as castes until very recently ${ }^{3}$. Together, the interface of a multitude of caste and cultural groups for a long period of time in this society has contributed to weaken the rigidity of many features that could be used to define their caste and cultural identities. Hamilton has a comment in this regard that what may be termed as "tribal" groups of Nepal are characterized by a relatively week notion of purity and pollution, relaxed food taboo, relaxed marriage rules and greater freedom of women (cited in Sharma 1978)

What is implicit in this remark is that most of the cultural groups of Nepal, even if they may not belong to Hindu caste categories, possess some features of caste group. The concept of Sanskritization may explain this characteristic. Interactions among different categories of the populations over a long period of time might have motivated many of the "tribal" groups or even the caste Hindus to change their "customs, ritual, ideology, and the way of life in the direction of high" caste (Srinivas 1966: 6). However, the influence of cultural contact on caste has not remained an entirely one-sided affair. Even the Hindus placed at the upper rank in caste hierarchy have followed some cultural features of other groups placed below them in the caste system or even outside that system. "Relaxed rules of inter-caste marriage, widow remarriage, easy divorce for women even among high-caste Hindus are some examples of this" (Sharma 1978: 6).

It should be remembered at this point that the influence of cultural contact on socialization has not been uniform to all groups of people living in all parts of the country. In terms of the magnitude of share of inter-cultural features, the population of Nepal can be grouped in three broader categories. These categories may be termed as the Bhote, Parbate, and Madhese. At one level, the people who are included in either of these categories reflect some connection with a particular geographical regions. Those, which may be termed as the Bhote, as will be noted below, inhabit in the 
high mountain zone close to Bhot or Tibet. The Madhese, on the other hand, are the traditional inhabitants of the Tarai or Madhesh region located along Nepal's the border in the south with India. The Parbate live in the hills and river valleys between the high mountain zone and the Tarai Region. However, such a categorization for the present purpose has a relevance to cultural differences of the populations rather than their affinity with a particular geographic region.

It is true that the features of culture of a particular region largely shape the culture and behaviors followed by people living around that area. This is one of the important reasons that the Bhotes have close affinity with the culture of Tibet (or Bhot) than that of the plains of India. "Bhote" is, however, a generic category, which incorporates a wide variety of endogamous groups of population. Jest prepares a list that the Bhotes includes the cultural groups like "Humla, Mugu, Dolpo, Lo (Mustang), Nar, Nyi-shang, Nub-ri, Tsum, Langthang, Sherpa and Helung" who reside from west to east at different parts of high mountain areas (1978: 359). To this list are added further some other groups like Baragaunle (Bista 1972) and some other divisions of the "Bhote" population (Gurung 1992: 19).

The separate identity possessed by various groups found among the Bhote is an indication that they all have been able to preserve some uniqueness in their respective cultures. However, there are also some commonalities in the culture of all these groups that they come together to form a single category when they are compared with the Madhese and the Parbate. Physically, the members in all the groups of the Bhote population have Mongoloid character. They speak Tibetan dialects, follow Buddhist religion and are least influenced by Hindu cultural tradition. Their economy is based on pastoralism, long distance trade across the border region, and cultivation of barley, buckwheat and potato in the high mountain zones and the inner Himalayan valleys.

On the contrary, the Madheses have a high level of cultural affinity with the peoples of plains of India. Most of them are the Hindus and are divided into a number of caste groups such as the Brahman, Chamar, Dom, Lodh, Kayastha, Kewot, Koiri, Kurmi, Mushar, Rajput, etc. The Tharus, one of the indigenous groups of population of this region, also make significant proportion of the Madhese population. Muslims are also found in some pocket of this cultural region. The region inhabited by the Madhese population is known as the granary of the nation. Land cultivation is the major occupation of people living in this area. This is also a region with a major concentration of industrial and business activities of the country.

The Parbates combine the features of both the Bhotes and the Madheses. Such a combination can be seen at the level of their racial composition as well as other feature of culture. Racially they are comprised of both the Mongoloid and Caucasoid stock. Gurung, Limbu, Magar, Rai, Tamang, Thakali, etc. are among the wellknown groups of Mongoloid population living in this cultural zone. There is certain area having major concentration of each of these populations (Bista 1972). In between them are interspersed the caste Hindus of Caucasoid origin. Brahman (or Bahun), Damai (tailors and musician), Kami (ironworkers), Kshatriya (or Chhetri), Sarki (leather workers), Sonar (goldsmith), etc. are among these caste groups, which are distributed in many parts of this cultural region. Each of these caste and ethnic categories has its own separate identity. However, the interface of a variety of cultures in the region has brought them together into a common bond of a broader groups of the Parbate population.

At one level, such an inter-cultural interface can be observed in the form of what has already been noted as the process of 
Sanskritization or Hinduization (Srinivas 1966). The cultural groups, which belong to Mongolid stock among the Parbates are racially close with the Bhotes. As a result, people belonging to both of these categories have many similarities in culture. Like in the case of Bhotes, Buddhism is the basic form of religion followed by Gurung, Tamang Thakali ${ }^{4}$ and other such categories among the Parbates. At the same time, all the Mongoloids among the Parbates are highly influenced by Hinduism.

It does not mean that Hinduism has made its influence to all the Mongoloids among the Parbates in uniform way. Its influence is very high among the Magars compared to other groups of this race. Although the process of Hinduization is not uniform even among the Magars of different areas, they worship Hindu gods and goddesses and use Brahman priests in ceremonial practices. They themselves also serve as the temple priests in many shrines ${ }^{5}$ of these gods and goddesses.

The Gurungs, Tamangs and Thakalis possess many features of Tibetan cultural tradition. About the cultural root of the Thakalis, Fürer-Haimendorf has noted, “... they conformed to the general pattern of Tibetan Buddhist society." He notes again about their changes that through the passage of time and their interaction with other groups of population, the young and educated Thakalis "in their striving for an improved status vis-à-vis Brahmin, Chhetri and Newar" "used the most tortuous argument to prove that the Thakalis had originally been Thakuris" i.e., members of the High Hindu caste." (1966": 143). About the Gurungs, as Macfarlane has commented, "[t]hey appear to incorporate the elements of both Tibeto-Burman and Indo-Aryan origin." (Macfarlane 1976: 12). They speak Tibeto-Burman language, observe some Tibetan religious festivals, and receive priestly services from members belonging to one of their separate clan known as "Lama." Together, they also celebrate Hindu festivals like the Dasai, Tihar, etc., and are divided into a number of castes having hierarchical status. These castes among the Gurungs are lumped in two broader categories known as Char Jat (four castes) and Sohra Jat (sixteen castes). All these Mongoloids among the Parbates keep similar level of social distance in their dealings with the castes that were traditionally regarded as untouchables.

Adoption of the features of Hindu cultural tradition by those social groups whose race was originated in non-Hindu areas suggests only one dimension of cultural contact among different groups of Parbates. Another dimension of such a cultural contact can be seen in the process of relaxation of norms of Hinduism that govern the relationship between people belonging to a variety of caste and non-caste categories. Specially, such a relaxation is pronounced in areas of food taboos, commensality rules and the status of children born of parents from inter-caste unions.

At least in urban areas, the youths born in Bahun and Chhetri castes, for example, are increasingly being less strict to observe the rules of food habits prescribed for members of their respective castes. According to conventional practices, members belonging to these caste groups are not permitted to take liquor, pork, chicken or even meat of any kind. However, the emerging practice has been that they do not feel any hesitation to take these food and alcoholic beverages without reducing their status in caste. Now a day, one's caste status is defined mainly in terms of the caste group at birth than the type of food someone takes in personal life. The ability to make a lavish supply of meet and alcoholic beverages has emerged in the form of a symbol of status among the families of highranking politicians, bureaucrats, and businesspersons of all caste categories during the feast they arrange at ceremonies like birthday and marriage of members of their respective families. Food taboos 
and commensality rules are observed within the household, and generally at times of worship and related religious ceremonies.

Hinduism endorses hypergamous type of inter-caste marriages. However, the status of offspring born of parents from this type of marriage relations is distinct among the Parbates. Specially, the children born of Brahman and Chhetri father and the mother drawn from any caste located above the margin of "untouchability" are regarded as Chhetris or the warrier caste. Although, the Chhetris also are divided into a number of ranked groups in terms of the caste of their mother, such a hierarchy hardly influence the selection of mates for members belonging to either of these categories (Fürer-Haimendorf $1966^{\mathrm{b}}$ ). However, a special category of Chhetris are found in western part of the country. They drink liquor, wear no sacred thread and are identified in the name of the Matwali (loquor drinking) Chhetri (Bista 1972). It is believed that these Chhetris are also the descendents of the Brahman and Chhetri fathers and the mothers from tribal groups. They acquired this status simply by reason that they did not observed the rules related to food taboos prescribed by Hindu caste regulation for their groups, when Hinduism was dominant in this area (FürerHaimendorf $1966^{b}$ ).

The process of Hinduization of those cultural groups whose race was originated in areas where Hinduism has no influence; the relaxation of caste rules among the Hindus as they come into contact with other categories of the population; and the emergence of a variety of caste and cultural groups through these types of interactions have made the cultural zone of Parbate population as a melting pot of diverse cultural tradition. The Newars represent the perfect example of a group which combine the features of a variety of cultural tradition. The facial and bodily structure of the Newars has made scholars to conclude that they are an "Indic subtype of the
Mongolians" (Doherty 1978:435). They are highly organized among all social groups of the country. They speak a dialect of Tibeto-Burman language family and follow both Hindu and Buddhist religious practices. Newars, like other Hindus among the Parbates, are divided into a number of caste groups ranking from Brahman to "Untouchables". Rosser counts 26 castes among the Newars of Kathmandu valley (1966:86).

There is, however, a fusion of Hinduism and Buddhist cultural tradition among the Newars in the valley of great civilization. Rosser points out that "[f]rom remote antiquity Hinduism and Buddhism have existed side by side in the Kathmandu valley producing a magnificent array of superb temples and stupas and ornate shrines" However, in the process of coexistence for a long period of time through the centuries "the strength and vitality of the Buddhist faith in the Kathmandu Valley appears to have undergone a steady decline" (Rosser 1966: 77-78). This process has been noticed also in the form of formation of caste groups even among the Buddhist of this population. As Rosser puts it again:

The Newar monks in the monasteries ... ceased to be celibate and became fully incorporated in the Newar caste system as a distinct and hereditary priestly caste. ...there are in the present day Newar caste system two separate castes at the highest level of ritual status with the traditional and hereditary occupation of being family priests. One of these Newar castes is Brahman and of course Hindu, serving all Hindu Newar families apart from the untouchables. The other is Buddhist and called Gubhaju, serving all Buddhist Newar families apart again from untouchables) (ibid: 78). $\mathrm{He}$ has, however, the observation that also the "Buddhism was tolerated without apparent discrimination and Buddhist temples were revered" even by the kings who themselves were Hindus. 
Within the past few decades, the process of inter-regional migration of population, and particularly that from the Hill to the Tarai region, has developed a trend to bring Parbates and Madheses closer to each other. The literature in the history of Nepal has recorded some evidence that since after the formation of present State of Nepal, there was some level of contact between the Parbates and Madheses even in the Tarai region. At least until mid- $20^{\text {th }}$ century, such a contact was limited in a form of Parbate landowners and their Madhese cultivators (Regmi 1976). After this period, opportunities allowed for the poor and marginal farmers of the hill region to explore cultivable lands in the Tarai. This process has provided an adequate opportunity for the interaction of people of both of these cultural zones. It is still a question of research to identify the intensity of their interaction. The migratory process, however, has helped to strengthen the feeling of nationhood among people living in both of these regions.

\section{Politics of Caste and/or the Caste System}

At its ideological level, one of the important features of the caste system, as noted above, is the division of labor according to caste groups. The 4 Varnas, as the ideological prototype of caste divisions in society, are required to perform four distinct activities. The Brahman at the apex of this hierarchy has the duty to provide priestly services for people belonging to other categories. The Kshatriya ranked below the Brahman in caste hierarchy, has the right to use power to protect people and society. The Vaishyas placed in the third rank of such a hierarchy are the farmers, grazers and producers. The lot of Shudras is to serve for the groups placed above them in the hierarchy. The "Untouchables" not incorporated in the Varna model form a fifth category of the impure Shudras and have the duties to serve their superiors in various ways.
Such a prescription of caste-based occupation and the requirement of hereditary membership in caste groups have many economic and political implications. Economically, this type of context poses severe limits on occupational choice for the population. The limitation to occupational choice is more pronounced for people located in lower than in upper rank in caste hierarchy. Those in the upper ranks may have chances to follow tasks prescribed for the lower castes, if they are willing to loose their original status. Nevertheless, the members of the lower rank cannot improve their caste status and follow the occupations prescribed for the upper castes. These differences in the limitations of occupational choice provide different level of power and privileges to members of different caste categories.

In fact, the Kshatriyas as rulers and the Brahmans as priests of the rulers have the opportunity to develop themselves into "the dominant caste" (Bailey 1960: 257-263) by concentrating in their hands most of the political and intellectual power of society. Such is, however, a theoretical possibility. In practice, this principle may apply differentially among different members of the same castes in different points of history of a society, or between societies even within a single point of time. Let us briefly make a historical overview of the application of this principle in the broader context of Nepal.

Hinduism continued to dominate the system of values of majority of people of Nepal all through the period since the beginning of human settlement in this area. Chhetri Kings have ruled over this country through all the period since its unification. As a result, the Brahmans have been the priests of these rulers through generations. However, caste as a system of social organization has been taken in different ways at different period of time by these rulers in the process of their system of governance. Until the $14^{\text {th }}$ century, and 
specifically before the time of King Jayasthiti Malla, as will be discussed below, Hinduism had its influence in society simply by way of practice of tradition. Of course, it was a dominant religion followed by a large section of society; it had not received any special favour by law of the country. Buddhism was also a popular religion among many sections of the population. At some points of the history, even the rulers were the followers of this religion ${ }^{6}$.

Jayasthiti Malla, the king of Kathmandu valley during the later half of $14^{\text {th }}$ century provided for the first time a legal recognition to caste based hierarchy as a prioritized form of social organization among the the people of Kathmandu Valley including the Newars. Through a campaign of what is generally known in the historical records of Nepal as a social reform measure of Jayasthiti Malla, his law divided the "great proportion of society into 64 castes" (translation mine) (Sharma 1978). There were many subdivisions even among these caste groups. In a summary report published of the "reform measure," it has been mentioned that among the Newars, the Shresthas were divided into 36 castes of which 13 were regarded as the sacred thread wearers; the Jyapus were divided into 32 castes; Kumals into 8 castes; Banda, Kushale and pode each into four caste; Khasha into 64 caste, etc (Budathoki nd: 6). Through such a measure, the caste system was received as a legitimate form of social organization in Nepal.

A more vigorous attempt to enhance the legal support for the entrenchment of caste-based organization of society was made by the Nepali State during mid $19^{\text {th }}$ century. Through the formulation of the Mulki Ain (Civil Code) in 1854, it tried to accomplish this task in two different ways (see Höfer 2994). At one level, the provisions of the Code attempted to expand the process of Hinduisation by carving the way to incorporate all ethnic categories into the caste system. For this purpose, the Code transformed the conventional categories of the Varna system into five broader caste categories (Table 1). This method allowed it to integrate all ethnic groups of the country into new framework of the caste system.

\section{Table 1: Caste Classification of the Mulki Ain (1854)}

A. Pure Caste (Chokho Jat) or Water Acceptable Caste (Pani Chalne Jat)

\begin{tabular}{l|l}
\hline Caste Category & $\begin{array}{l}\text { Caste Groups Incorporated in the } \\
\text { Category }\end{array}$ \\
\hline $\begin{array}{l}\text { 1. Wearers of the sacred thread } \\
\text { (Tagadhari) }\end{array}$ & $\begin{array}{l}\text { Hill Brahman, Tarai Brahman, } \\
\text { Thakuri/Chhetri, Sanyasi (ascetic } \\
\text { sect) and some Newars }\end{array}$ \\
\hline $\begin{array}{l}\text { 2. Non-enslavable alcochol-drinkers } \\
\text { (Namasinys Matwali Jat) }\end{array}$ & $\begin{array}{l}\text { Magar,Gurung, Sunwar, some } \\
\text { Newar caste }\end{array}$ \\
\hline $\begin{array}{l}\text { 3. Enslavable alcohol-drinkers } \\
\text { (Masinya Matwali Jat) }\end{array}$ & $\begin{array}{l}\text { Bhote, Chepang, Kumal,Hayu, } \\
\text { Tharu, Gharti }\end{array}$ \\
\hline
\end{tabular}

B. Impure or Water Unacceptable (Pani Nachalne) Caste (Jat)

\begin{tabular}{l|l}
\hline 4. Inpure but touchable \\
$\begin{array}{l}\text { (Pani Nachalne Chhoi Chhito } \\
\text { Halna Naparne) }\end{array}$ & $\begin{array}{l}\text { Kasai, Kusle, Dhobi, Kulu, } \\
\text { Musalman, Mlechha }\end{array}$ \\
\hline $\begin{array}{l}\text { 5. Impure and Untouchable } \\
\text { (Pani Nachalne Choi Chhito } \\
\text { Halha Parne) }\end{array}$ & $\begin{array}{l}\text { Kami, Sarki, Khadara, Damai, } \\
\text { Gaine, Badi, Pode, Chame }\end{array}$ \\
\hline
\end{tabular}

Source: Höfer 2004)

Note: The castes placed within the group "A" category may not accept water from those placed in group "B" so that the latter are labeled "water unacceptable". Enslavable castes are placed in group "B" so that the latter an be punished by enslavement for committing certain those caste groups whose members can be punished by enslavement for com category in the Table do not types of offences. The caste groups
necessarily follow their rank order.

Table 1 above presents the broader caste categories identified by the Code and the caste groups incorporated within them. This classification lumped together the wearers of sacred thread such as the Brahmans, Chhetris and others into a single caste category. It did not challenge the rank order defined for these groups by the 
conventional norm of the Varna system. What it did was simply to narrow down the conventional categories of the caste system and make it easier to add some new categories into it without creating much confusion. Accordingly, it placed together the Brahman, Chhetri, Sanyasi and some Newars into the apex of such a classification system. Below them in the caste rank was introduced a distinct category of the Namasinya Matwali Jat. The provision of the Code placed some of the important ethnic groups of the country within this category. However, many others also came under this category by practice of tradition. Through this process, they were brought under the umbrella of the caste system. The standard followed for such a ranking of their caste order was defined to be their consumption of alcoholic drinks. The remaining castes of the Varna system and some other ethnic categories were ranked below them. The code does not provide a comprehensive list of all caste and ethnic categories available in different parts of the country. However, it established a principle of the classification system under which they all find their place in either of the five broader categories, at least in practice of tradition.

In defense of the caste system, the Code also provided a legal sanction to relative differences of privileges enjoyed by members of different castes. In this regard, it specified their occupation, prescribed rules related to commensality and marital relations, and endorsed differential treatment in the application of law even for committing the same crime (Höfer 2004). The laws of the Code embraced "in letter and spirit the values and ideologies taught by the Hindu dharmsastric text" (Sharma 2004: xvii). They legitimized the rulers and their rules as the custodian of the caste system.

After the termination of the Rana rule, the state took a different approach towards its treatment of the caste system. With the introduction of Interim Constitution in 1951, it started to show its commitment, at least in theory, towards democratic ideals. The rules and regulations that came into being after this event gradually erased the legal support for any type of discriminatory practices based on the caste system.

It does not mean that Nepal was declared a secular state. Nepal's identity as a Hindu Kingdom was kept intact by provisions of all constitutions formed during this period. All the constitutions required the country to be governed by a Hindu monarch. However, they also established the principle that all people of the country, disregarding their caste identity, be treated equally before law. In 1963, a New Civil Code (Naya Mulki Ain) was introduced. This Code also declared the practice of untouchability as an illegal act. Through various provisions of its constitutions and laws, Nepali state has refused since the 1950 s to acknowledge its role as a custodian of the caste system.

The disavowal of the states to provide legal protection to caste based organization of society transformed its practice from public to personal domain of tradition. Now, it became a matter of personal choice for anyone to follow or not to follow their caste norms. However, it is required that each individual pay respect for the interest of other individuals while selecting his/her personal path.

Since the1990s, the state opened an environment conducive for the proliferation of a plurality of interest organizations. The freedom of choice allowed for people within the context of such an environment diverted the caste-based politics of the country into a different direction. Now, some interest groups are opened in the form of organizations of ethnic categories and those of the caste groups. The ethnic organizations have expressed their identity in the name of organizations of "Janajatis." These Janajati organizations sometimes urge the members of their respective groups to 
refrain from performing the Hindu rituals and avoid celebrating their festivals. Unitedly, these organizations through formulation of their federation have started to demand an adequate share in the system of governance for themselves.

The groups ranked as "impure" or "untouchables" under the conventional norm of caste-based hierarchy have also expressed their unity by identifying themselves into the single "Dalit" category. Like the Janajatis, the Dalits also have their organizations to communicate their collective demands and influence the government. With these developments, issues are being raised to consider ethnicity and/or the Dalit castes as units for the implementation of programs intended to solve some mundane problems like poverty (Kievelitz 1996; Bennett 2003).

The formations of these caste and ethnic based organizations and the demands they pose with the government have two important advantages towards democratization of society. At one level, they may help to break the concentration of power in the hands of the elites of a limited number of caste groups (see Caplan 1970; Caplan 1972 as an example of such a case even in the micro settings) by dispersing it through the expansion of the circle of elite in society. Once caste and ethnic categories are recognized as appropriate social units to implement programs of development in the country, the leaders of all caste and ethnic groups will have a chance to get an easy access to power with a minimum risk of competition. Secondly, caste and ethnic organizations, if equipped with power, may be the best units to implement programs addressed towards the promotion of cultures of their categories.

However, in the case of programs intended to solve problems faced by people at the level of their household units, caste and ethnic categories as a form of development units have to be considered very cautiously. Particularly when the problems are related to households' access to income and resources, selection of a caste or an ethnic category as a development unit suffers the risk associated with homogenization of the population. A caste or an ethnic group may be graded to a specific rank in terms of the aggregate features of its population. This aggregation by presenting the group in an image of a homogenous category covers up of the differential experiences faced by individual members of that category. Such a context leads to a situation that in some groups of society the elite themselves will have an opportunity to seize the fruits of development simply by reason that they belong to a caste or ethnic group in which a specific program is implemented. In others, even the marginal households will be deprived from having their share of such a benefit by simply the same kind of reason that they happen to be the members of a caste or an ethnic group, which is not selected to run the program.

A Brahman may be a priest, a Chhetri may be a king, a Newar may own a large business enterprise or a Gurung, Magar and Limbu may have an opportunity to receive a handsome salary by virtue of their recruitment in selected jobs in the foreign nations. The facilities and other chances of life enjoyed by these caste and ethnic elite do not represent the conditions of life suffered by general members of respective communities. There are evidences that the human development status of the population is very low in mountain and hill districts that part of the country where the Brahmans and Chhetris are in majority (see District Human Development Index in NPC/UNDP 2004: Annex 1.3, Table 2 and Dahal 2003). The status of such a development is not uniform even among the members within and between the other ethnic categories. Given this situation, it is not a caste or an ethnic group but the economic class of households that appears more appropriate to take into account as the unit for the implementation of development programs addressed to affect the economic life of any group of the population. Even if a 
caste or an ethnic category were taken into account, it would be useful to consider it in the context of a locality rather than a generalized category.

\section{Conclusions}

Above discussions help us to come to the conclusion that the interactions among people of different cultural traditions for a long period of time in the past have made two interrelated types of effects on caste as a system of values and social organization in Nepalese society. At one level, such an interaction has impressed many non-caste categories of the population to adopt the castebased values in the patterns of their social behaviour. At another level, such an interaction also contributed to erode the rigidity of those values even among members of caste groups as their behaviors were influenced by the cultures of non-caste people. However, the Nepali state at least from the late $14^{\text {th }}$ to mid $20^{\text {th }}$ century projected itself as a defender of the caste system. By using the state to endorse caste-based discrimination in society, the elite of some of the caste groups that were placed at the upper rank of the caste order also took many political and economic advantages. Since the 1950, the state has relinquished its role as a defender of the caste system. Particularly since the 1990s, the non-caste categories of the ethnic people as well as the caste groups placed at the bottom rank of the caste order have started to raise their voice for an appropriate share of their respective groups in the positions of power in society. These types of developments have a positive effect towards breaking down the concentration of power through allowing the expansion of the circle of elite in society. Yet it is not a caste or an ethnic group, but the economic class of the population that has to be considered as a social unit to tackle the problems related to differences in the distribution of resources and opportunities.

\section{Notes}

1. The terms "good caste" in this context make reference to those caste groups which are placed at the upper rank in the hierarchy of the caste system.

2. In the context of the caste system "Untouchable" as a caste group does not represent an indigenous category. Each of the caste groups, which are identified by this label, has its own caste name. "Untouchable" is therefore, a category developed by the scholars, which incorporates a variety of caste groups within a single unified category.

3. It is only after the formation of National Janajati Ayog (National Commission of the Nanajatis) during the decade of 1990s that the ethnic groups of Nepal became able to establish their non-caste identity in the legally recognized terms.

4. The original home of the Thakalis also lies in the Himalayan region, However, the involvement of members of this group into a variety of trade and business activities has pulled them down to interact with people in the major towns of the hills and the Tarai regions. As a result, like the other groups of mongoloids of the hill region they also form one component of the Parbate population.

5. To take few examples, the Magars are the priests of such famous temples as the goddess Manakamana of Gorkha, Alam Devi of Syanja, etc.

6. For example, King Manadev who is supposed to have ruled the Kathmandu Valley at some period of the last half of the $5^{\text {th }}$ century was a Hindu. His grand father is supposed to be the follower of Buddhist religion. Later, Shivadev first, who ruled the Valley during a certain period of time in the second half of the $6^{\text {th }}$ century is also supposed to have abdicated the throne by becoming a Buddhist monk. While the rulers may have their faith in one or another type of religious tradition, the state had not presented itself as a custodian of a particular form of religion until the time of Jayasthiti Malla in the $14^{\text {th }}$ century (see Sharma 1978 (2033), Part VI for details). 


\section{References}

Bailey, F.G. 1960, Tribe, Caste and Nation: A Study of Political Activity and Political Change in Highland Orissa, Manchester: Manchester University Press.

Béteille, André, 1964, "A Note on Referents of Caste" in European Journal of Sociology, Vol. V, pp. 130-134.

Béteille, André 1966, Caste, Class, and Power: Changing Patterns of Stratification in a Tenjore Village, Bombey: Oxford University Press.

Bennett, Lynn 2003, "Diversity and Inclusion: Contesting Hierarchy in Nepali Democtacy" Paper Presented in a Conference on The Agenda of Transformation: Inclusion in Nepali Democracy, Held in April 20-26, 2003 in Kathmandu.

Bista, Dor Bahadur 1972, People of Nepal, Kathmandu: Ratna Pustak Bhandar

Budhathoki, Chandra Prasad (nd), Jayasthiti Mallaka Sudharharu, (Reforms of Jayasthiti Malla), Kathmandu: Sajha Prakashan.

Caplan, Lionel 1070. Land and Social Change in East Nepal, Berkeley: University of California Press.

Caplan, P. A. 1972, Priests and Cobblers: a Study of Social Change in a Hindu Village in Western Nepal, London: Chandler Publishing Company.

Central Bureau of Statistics (CBS) 2002, Population Census 2001, Kathmandu: Central Bureau of Statistics.

Dahal, Dilli R. 2003, "Social Composition of the Population: Caste/ Ethnicity and Religion in Nepal" in Population Monograph of Nepal, Vol. I, Kathmandu: Central Bureau of Statistics.

Doherty, Victor S. 1978, "Notes on the Origin of the Newars of the Kathmandu Valley of Nepal" in James Fisher (ed.) Himalayan Anthropology: The Indo-Tibetan Interface, The Hague: Mutton Publishers.

Dumont, Louis 1972, Homo Hierarchicus, London: Gramada Publishing House.
Ghurye, G.S. 1961, Caste, Class and Occupation, Bombay: Popular Book Point.

Gurung, Harka 1992, "Representing the Ethnic Mosaic" in Himal, (May/June).

Fürer-Haimendorf, C. Von 1966", "Caste Concept and Status Distinction in Buddhist Communities of Western Nepal" in C. Von FürerHaimendorf (ed.) Caste and Kin in Nepal, India and Cyelon, Bombey: Asia Publishing House.

Fürer-Haimendorf, C. Von $1966^{\mathrm{b}}$, "Unity and Diversity in the Chhetri Caste in Nepal" in C. Von Fürer-Haimendorf (ed.) Caste and Kin in Nepal, India and Cyelon, Bombey: Asia Publishing House.

Höfer, András 2004, The Caste Hierarchy and the State in Nepal: A Study of the Mulki Ain of 1854, Kathmandu: Himal Books.

Hutton, J.H. 1963, Caste in India: Its Nature, Function and Origin, Delhi: Oxford University Press.

Jest, Corneille 1978, "Tibetan Communities of the High Valley of Nepal: Life in an Exceptional Environment and Economy" in James Fisher (ed.) Himalayan Anthropology: The Indo-Tibetan Interface, The Hague: Mutton Publishers.

Karve, Irawati 1961, Hindu Society: An Introduction, Poona: Deccan Collage.

Kievelitz, Uwe 1996, "Ethnicity and Nationalism in the Nepali Context: A Perspective from Europe" in Bhattachan, Krishna B. and Ganeh M. Gurung (eds.) Occasional Papers in Sociology and Anthropology, Kathmandu: Central Department of Sociology/ Anthropology, Tribhuvan University.

Macfarlane, Alan 1976, Resources and Population: A Study of Gurungs of Nepal, Cambridge: Cambridge University Press.

National Planning Commission (NPC)/ United Nations Development Programme (UNDP) 2004, "Nepal Human Development Report 2004," Draft, Kathmandu.

Pandey, Tulsi R. 2003, "Household, Community and the State: A Study of Modes of Livelihood in the Hill and Tarai Villages of Western Nepal", Ph. D. Thesis Submitted to Delhi University. 
Regmi, Mahesh C. 1976, Landownership in Nepal, Berkeley: University of California Press.

Rosser, Colin 1966, "Social Mobility in the Newar Caste System" in C. Von Fürer-Haimendorf (ed.) Caste and Kin in Nepal, India and Cyelon, Bombey: Asia Publishing House.

Srinivas, M.N. 1966, Social Change in Modern India, Berkeley: University of California Press

Sharma, Balchandra 1978 (2033 v.s.), Nepalko Aitihasik Ruparekha (An Outline of the History of Nepal), Baranasi: Krishna Kumari Devi.

Sharma, Prayag Raj 2004, "Introduction" in András Höfer, 2004, The Caste Hierarchy and the State in Nepal: A Study of the Mulki Ain of 1854, Kathmandu: Himal Books.

Sharma, Prayag Raj 1978, "Nepal: Hindu-Tribal Interface" in Contributions to Nepalese Studies, Vol. 16, No. 1, pp. 1-4.

\section{ADAPTATION AND IDENTITY OF YOLMO}

Binod Pokharel

\section{An Overview}

This article focuses on adaptation and identity of Yolmo people living in the western part of the Sindhupalchok district. The Yolmo are traditionally herders and traders but later they diversified their economy and are now relying on tourism, wage labour and work aboard for income. It is believed that they arrived in the Melamchi area from Tibet from the $18^{\text {th }}$ century onwards. This article basically concerns on how Yolmo change their adaptive strategy for their survival and how did they become successful in keep their identity even though they have a small population. The economic adaptation in mountain region is very difficult due to marginal land and low productivity. Therefore they diversified their economy in multiple sectors to cope with the environment. Bishop states that "diversification involves exploiting one or more zones and managing several economic activities simultaneously" (1998:22). Adaptation is an active process because neither the organism nor its environment remains constant. New problems and new solutions to the old problem arise. Each community has its own survival pattern. Such pattern is partly determined by environmental conditions and partly by socio-cultural system (Hardesty 1977). 